\title{
Belgeo
}

Revue belge de géographie

3-4 | 2008

Formatting Europe - Mapping a Continent

\section{Anthony Jenkinson's unique wall map of Russia (1562) and its influence on European cartography}

La carte de Russie de A. Jenkinson (1562) et son influence sur la cartographie européenne

\section{Krystyna Szykuła}

\section{OpenEdition}

\section{Journals}

Electronic version

URL: http://journals.openedition.org/belgeo/8827

DOI: $10.4000 /$ belgeo.8827

ISSN: 2294-9135

Publisher:

National Committee of Geography of Belgium, Société Royale Belge de Géographie

Printed version

Date of publication: 31 December 2008

Number of pages: $325-340$

ISSN: 1377-2368

\section{Electronic reference}

Krystyna Szykuła, "Anthony Jenkinson's unique wall map of Russia (1562) and its influence on European cartography", Belgeo [Online], 3-4 | 2008, Online since 22 May 2013, connection on 05 February 2021. URL: http://journals.openedition.org/belgeo/8827 ; DOI: https://doi.org/10.4000/ belgeo.8827

This text was automatically generated on 5 February 2021.

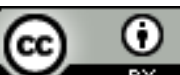

Belgeo est mis à disposition selon les termes de la licence Creative Commons Attribution 4.0 International. 


\section{Anthony Jenkinson's unique wall map of Russia (1562) and its influence on European cartography}

La carte de Russie de A. Jenkinson (1562) et son influence sur la cartographie européenne

Krystyna Szykuła

1 The Grand Duchy of Muscovy - the western part of Russia simultaneously covers the eastern end of Europe. One of the earliest maps of the country is also the most important document of the first travels of Englishmen, made as a result of searching for a proper route to China : the map of Russia made by Anthony Jenkinson, dated 1562. Until 1987, the author and his map were known only thanks to the famous Ortelius' atlas "Theatrum Orbis Terrarum". Until then, i.e. during more than four centuries, the genuine map had been considered lost and scholars could investigate only existing renditions - in Ortelius and de Jode's atlases.

2 Some very interesting theories were discussed at the time by scholars interested in the map in question on the basis of known renditions only. In particular, de Jode's derivative covers less than half of the territory represented by Ortelius, and the question then arose - who is right and whose rendition is closer to the genuine Jenkinson map. Now, we know that de Jode's rendition portrays only the upper left side of the original area, while the Ortelius version is faithful to the original.

\section{How was the genuine map rediscovered?}

3 Long thought to have been lost forever, the map was suddenly but unexpectedly rediscovered in 1987. The priceless map survived countless wars finally to be found after World War II by a school pupil, supposedly in her cellar ; she then gave it to her teacher as... a gift! The teacher used it for years as a teaching aid for history lessons unaware of the great value she had in her hands. 
One day, the teacher, who was since long retired wished to give her map to a library. She showed it to different libraries but nobody expressed an interest in it. Finally, because of the interest shown by the present author, it was purchased by the Wrocław University Library cartographic collection. The map had been used for years as a teaching aid and was thus in very bad condition - it was twice folded and brought to the library in a plastic bag. As soon as it had been acquired, the map was given into the hands of the library's Conservatory Division to undergo treatment for preservation. Whether fortunately or unfortunately, no ownership marks were found on the map.

Figure 1. The genuine Jenkinson's map.

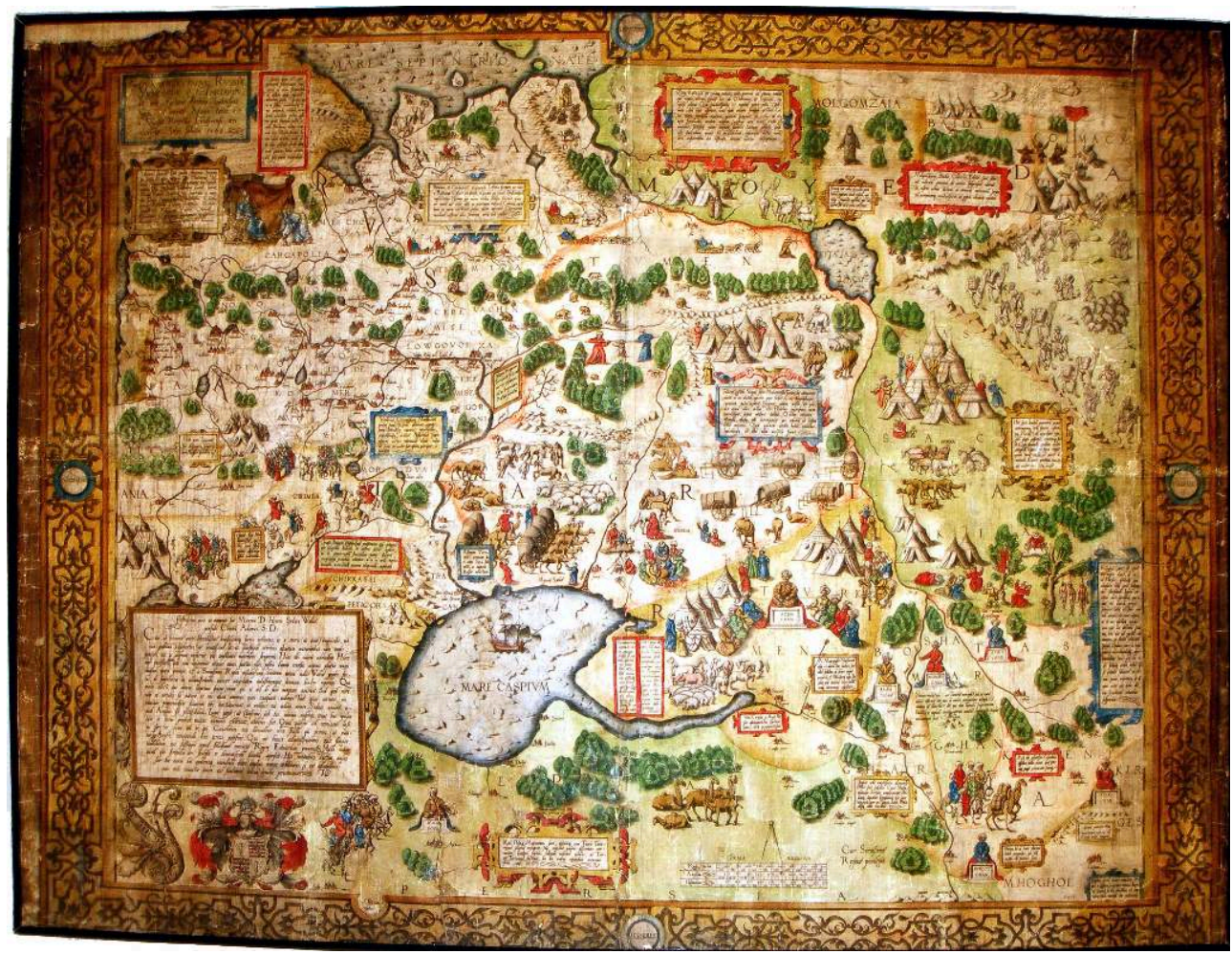

\section{First presentation of the map to the world of historians of cartography}

5 The map was presented soon after it was purchased by the library, i.e. at the $13^{\text {th }}$ International Conference on the History of Cartography held in Amsterdam in 1989. Two controversial points regarding the map needed confirmation. First, it had to be determined whether or not the map in question was indeed the only extant copy. Second, the relationship between the original and its renditions had to be shown.

6 The "find" of the genuine Jenkinson map "caused a stir among academics and dealers" - so wrote Valerie G. Scott - the chief editor of "The Map Collector" at that time. The same editor expressed her opinion in the account of the Amsterdam Conference entitled : "Map of Russia revealed at Conference". 


\section{The Jenkinson map as outcome of the travels of Englishmen}

7 The Jenkinson map is the final outcome of the author's own travels as well as those of his predecessors, among others Anton Wied (1508-1558), Sigismund Herberstein (1486-1566), William Borough (1539-1599) and many others before them such as Sebastian Cabot (? - 1556) or Richard Chanceller (? - 1556). Undoubtedly the significant role of Russian tsar Ivan the Terrible, who let Jenkinson travel through the whole of then contemporary Russia should also be stressed.

8 As far as Jenkinson's route is concerned, his first journey to Russia began on 12 May, 1557. He embarked from London, skirted the north coast of Scandinavia to Wordhouse - the castle Cape Kegor, entered into the Bay of S. Nicolas and through Colmogro, the river Dvina, the city of Ustiug, joined the country of Permia to the great city of Vologda and finally reached Moscow where he was invited to the court of Ivan the Terrible (6 December 1557). He traveled then on the great Volga river. One of the routes of the Jenkinson's travels led to the city of Boghar in Bactria along the Caspian Sea. Another route he traveled crossing the city of Derbent, reaching the court of the great Sophy of Persia and living there 8 months.

\section{The genuine Jenkinson map and its relationship with Ortelius and de Jode's renditions}

Before the Jenkinson map had been rediscovered, scholars could investigate only existing renditions. This event enabled us to show that the Ortelius derivative was the more faithful, especially with respect to the territorial scope, although the ornamentation was much poorer. The original turned out to be much larger than Ortelius' 44 by $35,3 \mathrm{~cm}$; it measures almost 102 by $82 \mathrm{~cm}$, including a $6 \mathrm{~cm}$ border. Contrary to Ortelius, de Jode "cut out" the eastern and south-western portion of the genuine map considered reliable.

The title cartouches on the maps under consideration differ, both in their contents and location. In addition, the full text of the dedication to Henry Sidney - the map sponsor - was revealed. It is placed in the bottom left corner of the map, while on the Ortelius map it is in the title cartouche and only mentions Sidney. On the genuine Jenkinson map the cartouche is located in the upper left corner.

11 As far as the cartographic content - including geographical names - is concerned, the left part of the map is more detailed. There are seas, lakes, rivers, mountains, forests, symbols of towns, boundaries of khanates and countries.

Worth mentioning is the location of a very large lake in the eastern half of the map. The lake, two main rivers and some names are practically the only geographical elements in this right portion of the map. This lake has been called Kitaia lacus, i.e. Chinese Lake, and the two rivers - Amow and Sur. Since we know that in the part of Siberia no big lake exists, we could come to the conclusion that it might be the Aral Sea with the rivers Amur-Daria and Syr-Daria on the Jenkinson map shifted only to the north part of Siberia. Maybe this supposition could be confirmation of the fact that William Borough travelling along the coast of north Russia reached only the lower 
stream of the Ob river, which on the map has a much shortened flow into the Kitaia lacus.

The river called on the map Ougus (known at that time as the Oxus, and to-day as the Amur-Daria) flows from the mountains called there "montes paraponisi" (Hindukush to-day), and into the Caspian Sea. In many sources including not only maps but written works, too, we can find confirmation of this fact. However, Jenkinson most probably took over this image from Ptolemy's map. We cannot exclude, either, that the river in early times changed its course as mentioned above.

A large space of the map consists of decorative elements. We can admire very interesting genre scenes, figures of warriors, i.e. Tartars and Cossacks, camps of nomads, their carriages and animals, the pagan god called "Zlata Baba" (Golden Woman) and lastly the image of Tsar Ivan the Terrible sitting on his throne and probably Jenkinson bowing before him. These decorative fragments of the map we can assume come from Johannes de Schille the painter who is mentioned in the letter written by Reinoldus - the engraver of the map in question - to Ortelius. The letter is preserved in the British Library and quoted in the correspondence of Ortelius. It is very interesting in various other respects, too. There is an information regarding 25 copies of the map that Reinoldus sent by order of Reginald Wolf - the king's typographer, maybe the printer of the map in question.

Recognition of the genuine map not only brought fresh knowledge about its details but also raised some problems. One was the date which was confirmed on the original map, but became a controversial point of discussion. During a scientific stay in Cambridge the present writer was lucky to find a heraldic work with the coat of arms - the same as that on the map and belonging to Henry Sidney, the sponsor of the map - which had been conferred upon him in 1566. The date was also confirmed by Prof. Samuel Baron, though by another fact, i.e., two journeys made by two Englishmen - Spark and Southam who influenced the geographical names used on Jenkinson's map. This leads us to put the date of the map at about 1567.

This valuable work had an early influence on the later cartography of this area, i.e. on maps by the Van Deutecum brothers (the so-called Daškov map - the family name of $19^{\text {th }}$ century collectors) of 1569 and in 1570 in Ortelius' first edition of the Theatrum Orbis Terrarum.

The next controversial question turned out to be Jenkinson's authorship because of the new information provided in the cartouche of the genuine map. In particular, besides Jenkinson as the author and Sidney, the sponsor (both known from the Ortelius map), the cartouche of the genuine map mentioned two new co-creators : Nicolaus Reinoldus, the engraver, and Clement Adams, the editor. Some scholars speculate that these three co-creators - Sidney, Adams and Reinolds - had a greater predisposition to map making than any merchant or explorer, as Jenkinson is usually described. On the other hand, sufficient proof of Jenkinson's authorship should be his diary in which he included his own surveys of distances and geographical latitudes. Furthermore, all three cartographers, Van Deutecum, Ortelius and de Jode, attributed the map's authorship to Jenkinson. We should also take into account that the map was made only on the basis of information provided by Jenkinson.

18 A detailed comparison of the map under consideration with other maps of Russia made by different authors of that period led to an interesting conclusion. Morgan and coot were the first to express an opinion that the northern part of the map was based on the 
Borough brothers' map, the western part on the Wied map, and that only the eastern and southern parts were by Jenkinson himself. The same scholars also claim that Münster's map became a model for Jenkinson's ; it may have been one but not the only one, because as we know Münster's map was much generalized, while Jenkinson's is more detailed. Bearing in mind that on Jenkinson's map the Amur-Daria (there called Ougus) is flowing into the Caspian Sea we should also see the influence of Ptolemy's map. Relations among the cartographers of that time have already been described by this author in a paper published in Polish (Czasopismo Geograficzne, Wrocław 2000) ; a shortened English version (published by the National Library, Warsaw) is accessible on Internet.

Figure 2a. The cartouche on the De Jode rendition.

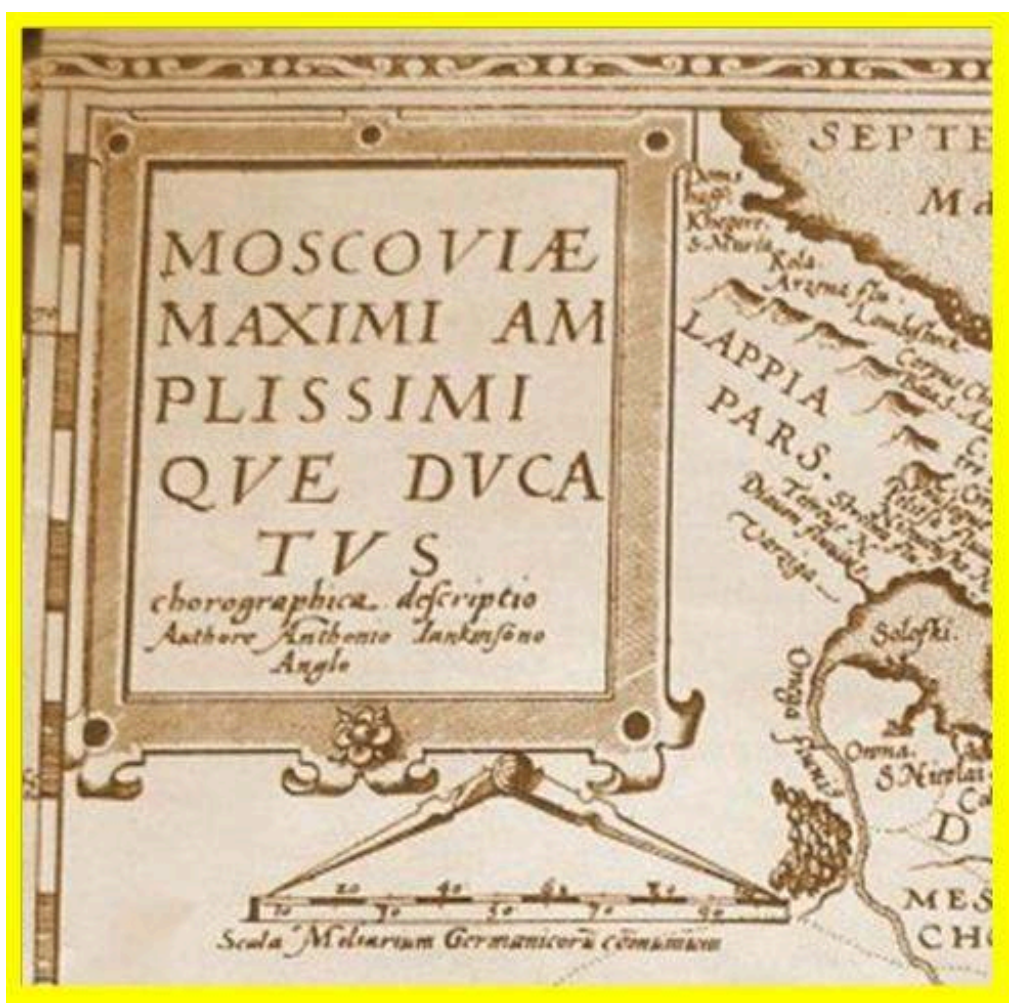


Figure $\mathbf{2 b}$. The cartouche on the genuine Jenkinson's .

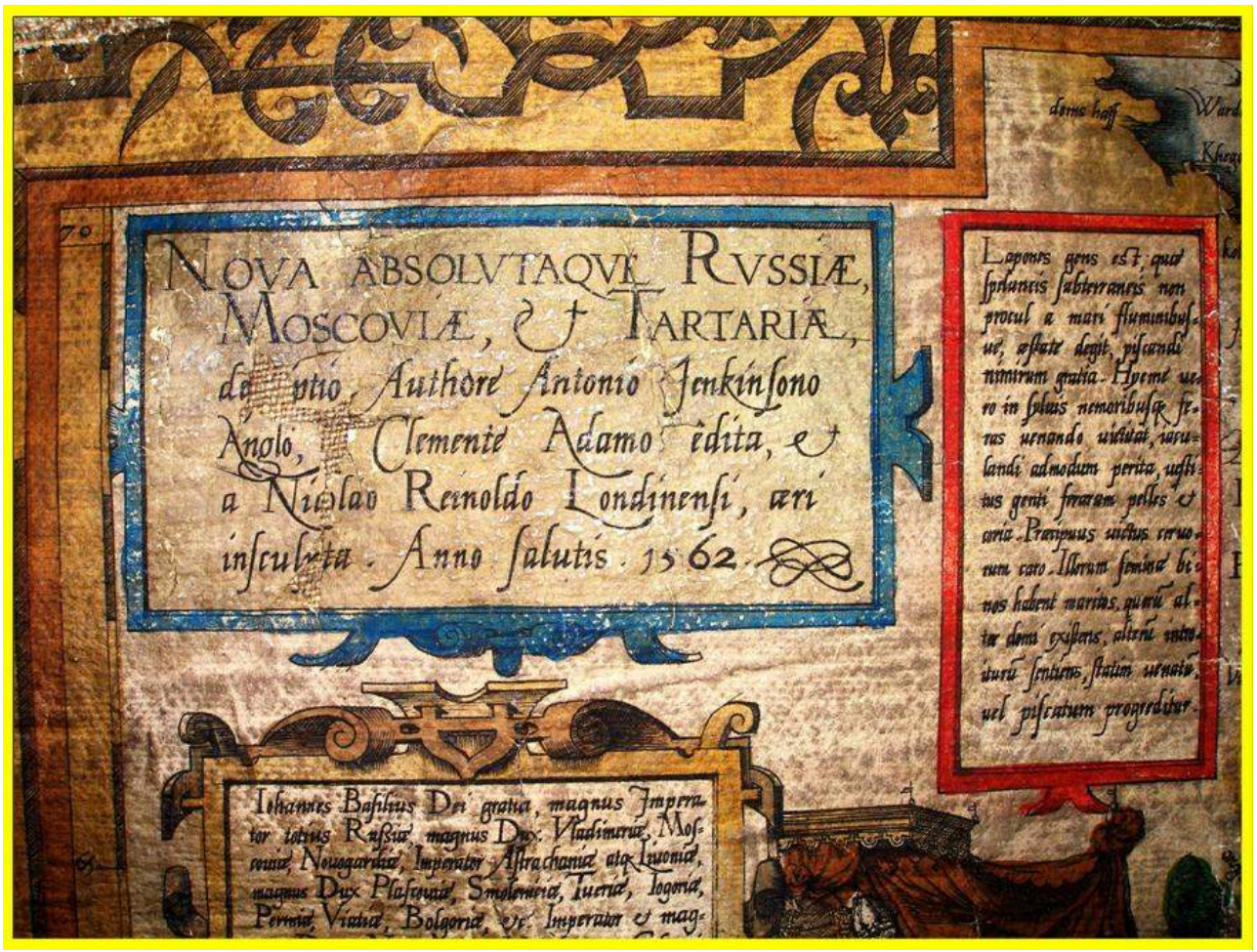

Figure 2c. The cartouche on the Ortelius rendition.

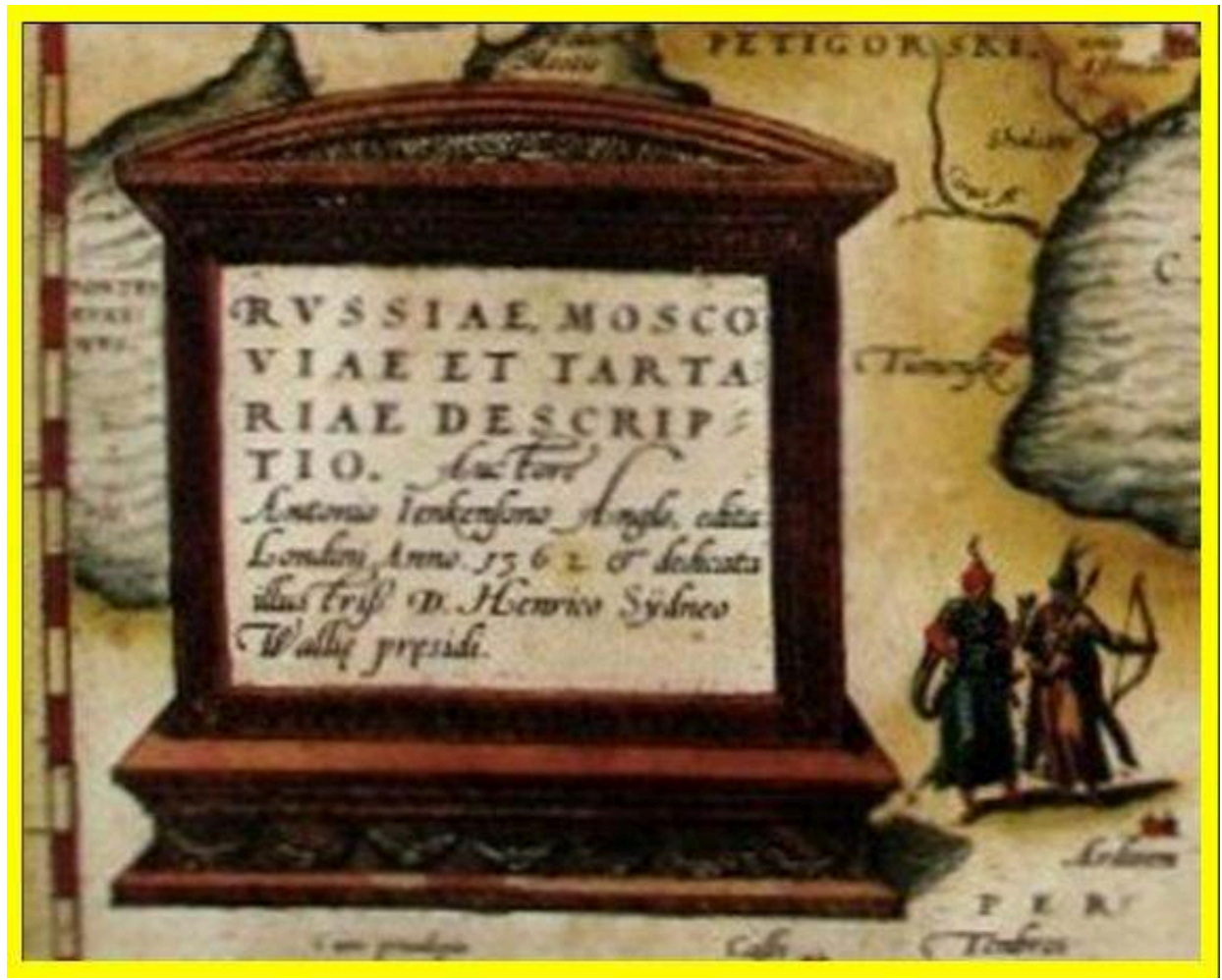




\section{The Jenkinson map territory performed by other cartographers of that time}

19 The comparisons made between the Jenkinson map and its renditions have shed a rather one-dimensional light on the documents. Of equal importance in any analysis of the Jenkinson map is an attempt to establish the sources of the Jenkinson's information and how his map relates to the cartographic works of his predecessors. Morgan and Coot, cited in S.H. Baron's article, were familiar only with the later renditions of the map from which they concluded that Jenkinson was the author of only the southern and eastern parts of his map, having borrowed the northern portion from the Borough brothers and the western portion from Anthony Wied. Their conclusions, however, need to be re-evaluated in the light of the rediscovery of the original map. A new analysis was made on the basis of the following maps : two maps by Waldseemüller from 1507 and 1512 ; Gerasimov's map in the 1525 Agnese atlas, and a Wied map of 1542 ; Münster's Cosmography of 1544 ; Herberstein from 1546, and finally, Gastaldi from the 1548 version of Ptolemy's Geography. In addition, the Jenkinson map was compared with three maps from an earlier, 1482 edition of Ptolemy's work that covered the same territory as the Englishman's map.

The second edition of the Wied map was also taken into consideration - though it appeared after the Jenkinson map the same year as the first edition of the Ortelius atlas - in order to establish if the Jenkinson map influenced it in any way.

21 These maps can be divided into two basic groups: the first group includes the schematic maps as well as the works of Ptolemaeus, Waldseemüller, Gerasimov-Agnese, Gastaldi, and Münster ; the second group includes the first detailed maps of Russia by Wied and Herberstein. From the very first glance it is clear that all the maps in both groups differ so much that one could surmise that none of the authors referred to the works of his predecessors. The Waldsemüller maps, for example, tend to exaggerate mountain chains and provide detailed place names: his 1507 chart greatly overemphasizes the size of the Black Sea and even more that of the Azov Sea, though the latter was corrected in his 1516 edition. The influence of Ptolemy is still evident, particularly as regards the manner of depicting mountains on the earlier map ; both works contain the famous but erroneous representation of the nonexistent mountains in the northern part of Russia which goes back to Ptolemy. The predominant element on the Gerasimov -Agnese and Gastaldi maps are the water networks ; additionally, Gerasimov emphasized lakes and Gastaldi forests. The Münster map, however, appears to be more schematic, but at closer examination proves to be closer in proportions to one of the contemporary maps of the area. Maybe the same projections on were used on these two maps! These proportions are much less accurate in the Herberstein and Wied maps, though both were ascribed to the second group of more detailed maps ; this should not, however, be confused with the overall geographic accuracy of these maps as such. It should be noted here that the Wied map is exceptionally difficult to read due not only to its south-eastern orientation, but also because of the dense layer of forest drawn over most of it and in particular its left half. The Wied map is not the only one to depart from the accepted northern orientation : the Münster map uses a north-eastern orientation, as does the Herberstein map, though according to the text on the border of the latter map it also purports to have a northern orientation. 

above maps taking several specific characteristics into consideration. In the first place, it is certain that Jenkinson did not copy the Ptolemy error from Waldseemüller and that, in fact, his map does not resemble any of the above-mentioned maps in its general outline. He did, however, borrow from Ptolemy the "Ougus" river, mentioned earlier, that flows into the Caspian Sea. Jenkinson may also have copied the latitudinal shape of the Caspian Sea from Waldseemüller and Gerasimov, for the simple reason that the other maps do not include this body of water.

A general survey of all the maps under discussion indicates that they all differ quite significantly with regard to the method in which each map represents various physiographic elements. The discrepancies in territorial representation are also conspicuous.

As mentioned above, the China Lake was one of the elements included in Jenkinson's map that the author borrowed from his predecessors Gastaldi and Herberstein. To his credit, however, Jenkinson removed the information regarding China and its capital to the right lower edge on the border of his map, where he wrote that "the border of the China Empire begins thirty days journey east of Kashkara", and that "from this border to Cumbalcu (one of the versions for the name of Peking used at the time) is another three months travel".

pared with Wied, Jenkinson's charting of the Suchan river (a tributary of the Dvina) is more accurate. His drawing of the Kama and Vyatka rivers is also better ; Herberstein did not mark the Vyatka at all. Jenkinson, on the other hand, mistakenly labeled the Neva river the Volga; his other errors include the Vlock lake, the China Lake and the area around the Ougus river.

In general, Jenkinson's map, in terms of its elaborate decorative contents, can be compared only with the Wied map. The so called "Zlata Baba" (Golden Woman) - a goddess revered at the time is, however, a curious element that appears on the maps by Jenkinson, Wied and Herberstein. On all three maps the goddess is situated near the lower Ob, though in three different renditions. Wied and Jenkinson depicted the goddess in the form of a woman on a pedestal surrounded by worshipers, whereas Herberstein left the woman on a pedestal. Münster drew in the same spot on his map the figure of an animal standing on a pedestal. The superiority of Jenkinson's map lies, inter alia, in the fact that he marked latitudes along the left- and right-hand sides of the map's frame. Another advantage of the Englishman's map is the more accurate and proportional positioning of orientation points such as towns.

The Wied and the Jenkinson maps are linked in a sense by a similar border : both are framed by what is called a metal construction, though on the Wied map it is a more elaborate and delicate leaf design. The Jenkinson map, however, is clearly unique in the author's use of numerous texts scattered throughout the entire map that provide interesting information about history and customs of the territory.

In response to the question posed above as to how the second edition of the Wied map relates to the first edition and with the Jenkinson map, we can say that undoubtedly the later Wieds edition is more legible, although in a smaller scale than the first. Wied gave his second map an eastern orientation, the same as on the earlier edition, though given some of the physiographic elements it appears that this is somewhat misleading. 
It depends, really, on which element one uses as a reference point. For instance, if one uses the position of the Black and Caspian Seas, Wied's orientation appears to be southeastern ; if one refers, however, to the course of the Ob river and the northern coast of Russia, then his orientation is indeed eastern. Rather than "omitting the mistake" made later by Jenkinson, Wied simply shortened the distance between north and south. In final analysis one may conclude that there are no significant differences between the two editions of the Wied map and that Jenkinson's map did not have much influence on Wied's map of 1570 .

Figures $3 a-3 b$. The coats of arm on the genuine map - The coats of arm had been conferred upon Sidney in 1566 ; this allowed to date the map to about 1567.

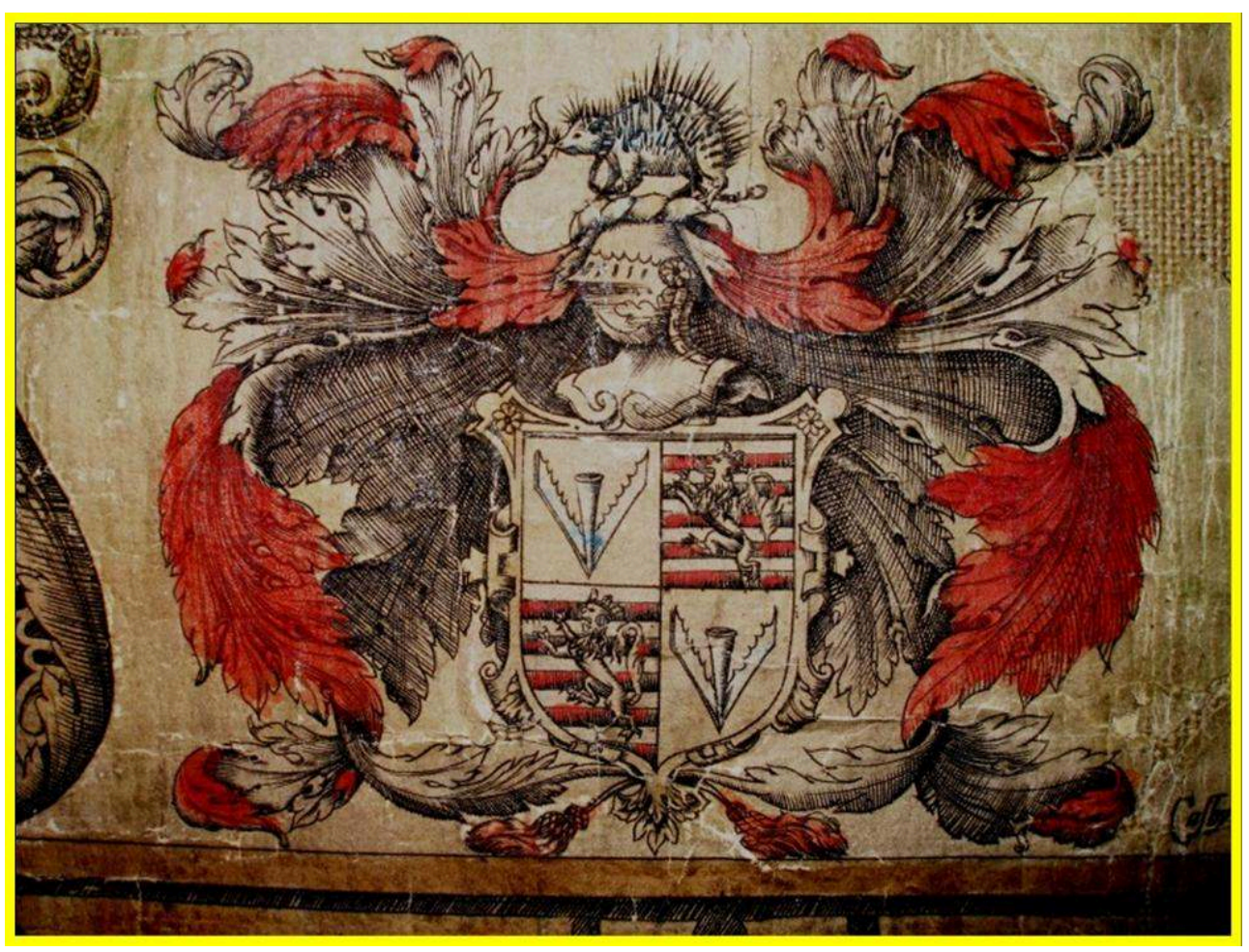




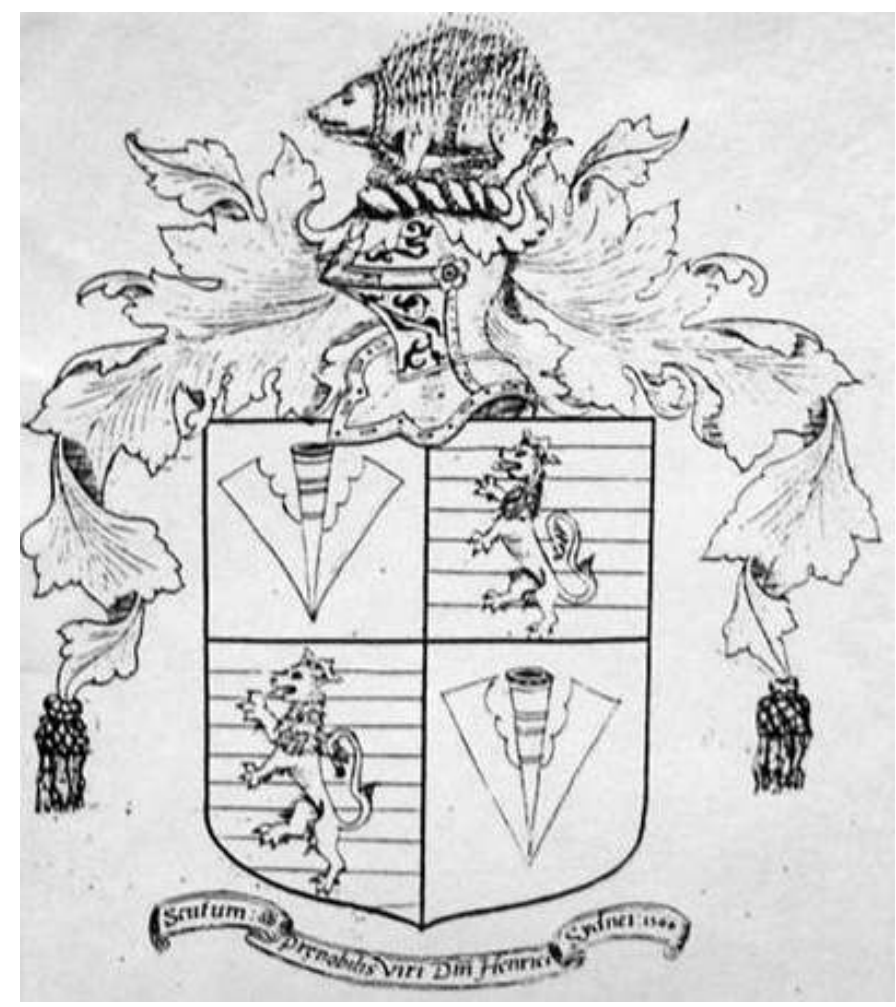

\section{The Jenkinson map territory in the post Jenkinson's maps of Europe}

Now, according to the title of this paper, the present author proposes to undertake another task, i.e. to analyze the influence of the rediscovered map on later cartography and to answer the question whether Jenkinson's map influenced the image portrayed by the post-Jenkinson cartographers of the $16^{\text {th }}, 17^{\text {th }}$ and $18^{\text {th }}$ centuries.

General maps of Europe only will be examined here, because maps of fragments of territory shown on Jenkinson's map, and also published at that time, call for a quite separate study and article.

Before we turn our attention to the post-Jenkinson maps of Europe it is worth recalling some pre-Jenkinson facts of the region in question.

It is worth mentioning the fact that from the earliest times Russia was represented by different words. For example "Tanais" (to-day the Don river) was inscribed on T- 0 maps, or "Caspium Mare" on Indicopleustes' map of the $6^{\text {th }}$ century. The Black Sea is called "Eusin Pontus" on Beatus Liebenensis map of the $8^{\text {th }}$ century and on the Ebstorfer map of the $13^{\text {th }}$ century. On the last-mentioned map we notice the names : "Caspium Mare", "Scithia" or "Moscovie" portrayed there as a city.

Especially worth mentioning is the map by Fra Mauro of 1459 - there the Don and Dneper rivers as well as the Black Sea are very accurately described. The same in the Rotz map of 1542 where the accuracy of the depiction of that sea is remarkable. Finally mention should be made here of the map of Europe by Münster (1560), drawn with south orientation but poor in content and in geographical names. 


\section{Post-Jenkinson maps of the second half of the $16^{\text {th }}$ century}

The last quarter of the $16^{\text {th }}$ century, i.e. the post-Jenkinson period, will be examined here. Based on Jenkinson's knowledge from his travels to Russia the map by the Deutecum brothers of 1569 should be considered here as a third derivative, although made in quite another projection than Jenkinson's genuine map and its two above mentioned renditions. The difference between the Van Deutecum map and the two known renditions is that this author treated Jenkinson's genuine map as only one of the sources which included Herberstein's work.

1570 was not only the year of Ortelius' rendition but also the year of the map of Europe which became the logo of the present Brussels Conference. Although the map is rather empty there are some names concerning Jenkinson's area such as "Scythia", "Tartaria", "Moscovia" and "Livonia". There are even two rivers of our region - "the Tanais" and "Borysthen" (the Don and Dneper rivers). The later map of Europe by Ortelius in his "Epitome" of c. 1598 is interesting because there he portrayed the very long "Volga" joining "the Mar Bachu" (the Caspian Sea) with the Baltic Sea, and Tartaria is situated in the north of Russia close to the White Sea. The well known and beautiful map by Hondius (1595) is especially in its decorative elements based on the Jenkinson map. In his wall map of Europe Mercator undoubtedly used Jenkinson's map, especially because he had, as we know from a letter of that time, his map sent to Ortelius for him from London.

Worth mentioning with regard to the area under consideration are the events which took place in the $16^{\text {th }}$ century. It was the time when Polish authors of works and maps corrected the mistake made by Ptolemy concerning the Riphei and Hiperborei mountains (Miechovita, 1517) and the estuaries of the Don and the Dnieper rivers, and in consequence the Black Sea. However, contrary to these developments, until the $18^{\text {th }}$ century some cartographers copied the image of the Ougus (Oxus), i.e. the Amur-Daria river, as will be described in this paper.

\section{Early half of the $17^{\text {th }}$ century}

Understandably we can observe a much more detailed development of maps of Europe in the $17^{\text {th }}$ century. In the early half of the $17^{\text {th }}$ century there are maps by: W.J. Blaeu (1606), J. Hondius (1606), G. de Jode (1613), one by C. Ptolemaeus (1621, Padua edition), two different maps by J. Speed (1626 and 1627), J. Hondius - J. Jansson (c. 1638) and M. Merian (c. 1650).

On these maps there is a richer toponimy, especially along the Dvina river. Empty places are filled with forests, descriptions and genre scenes. Worth mentioning is the map by Hondius of 1606 - probably his diminished and reduced version of the 1595 wall map. It covers the lesser known portion of the eastern part of the Jenkinson area, namely "Sir Hugo Willoughbes Landt" close to "Novaya Zemlya" discovered by the Sebastian Cabot expedition which was organized to look for the North East Passage to Catay in 1553. 

on Jenkinson's map mentioned above. The Black Sea is shown as "Mare Maggiore". As on Jenkinson's map there is the shortened Ob river with the Chinese Lake. The name of "Mare Septentrionale" appears with John Speed, too. However on Merian's map of Europe (c. 1650) the name of the Northern Sea is changed again to the "Murmanskoy More". The Black Sea there is named "Pontus Euxinus", and the Caspian Sea as "the Caspian Sea or Hircian".

Figure 4. The Caspian sea on the Homann's map of Europe ( $18^{\text {th }}$ century).

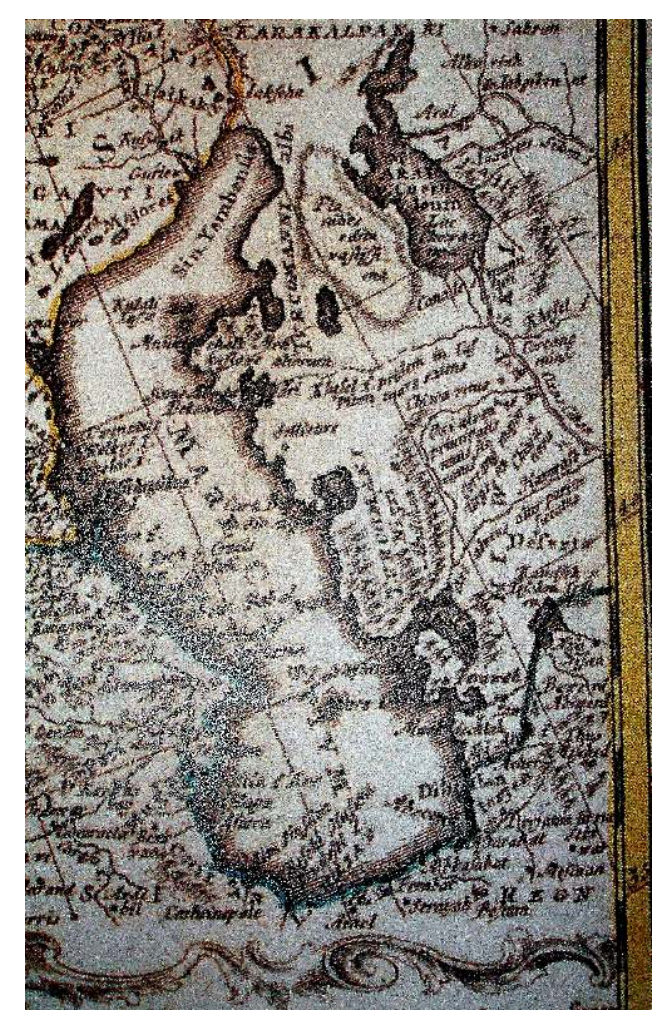

\section{Latter half of the $17^{\text {th }}$ century}

$$
\text { The }
$$
well as the $\mathrm{Ob}$ river with the Chinese Lake. In the north, the sea is still called "Mourmanskoy More". The most detailed image on his map which he portrayed including geographical names is the basin of the Dvina river and its two main tributaries - the Suchona and Wytsh(?)egda. The same date features on the map by F. de Wit. As on the abovementioned map, it portrays the same range of territory.

The map by Nicolaus Visscher is one of the early maps of the latter half of the $17^{\text {th }}$ century. It dates back to 1660 . The author has carefully excluded the Caspian Sea as In the seventh decade of the $17^{\text {th }}$ century two quite different maps were made by John Speed. One of them in sepia (small and uncolored) comes from an unidentified work but embraces the area including "The Caspian or Hircanum Sea", but not the Ob river and the Chinese lake. Also missing are two big lakes Ladoga and Onega which on the other 
hand were depicted on Jenkinson's map, although they are not quite correct in shape ("Vladiscoy lacus" and "Biatla ozera").

of little interest is a large map by Robert Morden which comprises the "Oby" river with an unnamed lake but equally an inscription "Bounds of Europe".

Finally of great interest, although too stretched in the east-west direction, is Coronelli's map of Europe, probably one of the gores of his globe because it is widely stretched to the south. Striking is the huge island "Nova Zembla", although it does not look like an island because it is joined to the mainland. The sea in the north of Russia here is named "Oceano Setten", and closer to the White Sea - "Mare di Moscouia", and the Black Sea is named as "Mare Negro" or "Mare Maggiore". Here the Azov Sea is named "Mare della Zabache sive della Tanas". An interesting feature of the same map shows the highly developed outline of the coast of lake Onega with as many as 13 rivers.

\section{Early half of the $18^{\text {th }}$ century}

At the beginning of the $18^{\text {th }}$ century, J. Jansson continued his activity and his map of Europe is dated c. 1700. Later cartographers are : G. de l'Isle (1700), E. Wells (1712), J. A. Montecalerio (1712), N. De Fer (1716 \& 1717), J. M. Hase (1720), N. Visscher (son? 1726), J.B. Nolin (1737), J. Cary (1740) and L. Valk (undated). In contrast to the abovementioned Coronelli map, we have a very important map of Europe (1700) with much earlier improved dimensions of the European continent, i.e. with a "Mediterranean Sea" shortened by 20 degrees ; a well-known mistake made by Ptolemy, first improved by Mercator by 10 degrees and finally corrected by De Lisle. The map in question exhibits a very interesting nomenclature for the western portion of Russia. Proceeding from the north we have "Laponie Moscovite", "Moscovie Europe" and "Moscovie Asiatique". The seas are "Mare Glaciale" in the north and "Mer Noire" (Black Sea) ; "Russie Moscovite" is shown as a part of "Moscovie Europe“. The estuary of the Wolga river is portrayed here differently from the Jenkinson map and from the image on contemporary maps where the delta estuary is clear.

of the later maps worth mentioning is the map of Europe of 1720 by "Joh. Matth. Hase" - a well-known employee of the Homann publishing house. It portrayed the first correct image of the Caspian Sea ("Mare Caspium" on the map) and for the first time the Aral See with the estuary of the "Oxus" river flowing from the south. There is also the much more detailed general content of a distant Russian territory ; for the first time it shows the "Iennisea Province".

48 The maps of the next cartographers, by Seutter and Schreiber, follow in detail the rest of Jenkinson's area on their maps.

In circa 1736 Hermann Moll devoted a special map to the Caspian Sea giving yet another name to this sea, the "More Cualenskoi".

Strangely on their (undated) map, Leonard and Gerard Valck took a step back to portray the Caspian Sea in its old shape calling it "Mare de Sala". The same sea is correctly depicted again on the map by John Cary in 1740 .

We can see one more name for the northern sea on Thomas Kitchin's map (c. 1750) where it is called the "Two Ice Sea".

Very intriguing and a big step back is the name on Schenk's undated map of that period, namely "Riphei montes". As is well known, these mountains were a major 
mistake made by Ptolemy, but corrected already by Miechovita in his "Tractatus de duabus Sarmatiis“, 1517, although on Ptolemy's map they were in the north part of Muscovy, whereas on Schenk's map they are in the middle basin of the Volga river.

\section{Latter half of the $18^{\text {th }}$ century} pointing out what the discovery of the map had brought :

1. A new image of the map itself - both to the general view and in terms of its size ;

2. Confirmation of the territorial scope portrayed by Ortelius in his rendition, as opposed to De Jode's ;

3. The differences in arrangement and contents of cartouches and the number of boxed texts including a long dedication to Henry Sidney - identified as the sponsor of the map ;

4. The new co-creators of the map in question : the engraver - Nicolaus Reinoldus and the editor - Clement Adams - both generally known but not connected with Jenkinson's map before ;

5. The wealth of decorative elements on Jenkinson's map brought forth new material to be studied, i.e. more numerous and more detailed genre scenes and a very decorative border of the genuine map.

To conclude the second part of the paper we can sum up by comparing the genuine Jenkinson map with the later post-Jenkinson maps of the $16^{\text {th }}, 17^{\text {th }}$ and $18^{\text {th }}$ centuries. Generally speaking the map's influence is not too significant. We can even say that authors who made maps of Russia or Muscovy used different map sources mostly 
having no occasion to check the information in native sources. Like Mercator, they probably used different maps, compiling them and indicating for example the same city several times because it frequently had a different spelling on subsequent maps. As we have seen in this paper, for example, the northern sea or the Black Sea had many different toponyms.

As a final result of this investigation a monograph with thematically arranged chapters, a facsimile edition of the genuine Jenkinson map and a dictionary of geographical names on the maps compared is in preparation and planned for publication.

One of the ethnographical description in Jenkinson's diary (in early English)? Upon the sea coast dwell Samoeds, and their country is called Molgomsey, whose meat is flesh of Olens, or Harts, and Fish and doe eate one another sometimes among themselves.

And if any Marchants come unto them, then they kill one of their children for their sakes to feast them withall.

And if any Marchants chance to die with them, they burie him not, but eate him, and so doe they eate them of their owne countrey likewise.

General remark: a comprehensive bibliography concerning the subject under consideration has been given in the abovementioned publications of the author.

\section{BIBLIOGRAPHY}

BARBER P. (1989), “Additional information on Jenkinson map”, The Map Collector 48, p. 39.

BARON S. H. (1993), “The lost Jenkinson map of Russia (1562). Recovered, redated and retitled", Terrae Incognitae, 25, pp. 53-66.

JÄGER E. (1989), “Die XIII. Internationale Konferenz zur Geschichte der Kartographie in Amsterdam", Nordost-Archiv 22, 96, pp. 239-245.

KARROW R.W. (1989), “Amsterdam Conference on the History of Cartography”, Map Line 55, pp. 1-5.

SCOTT V. G. (1989), “Map of Russia revealed at conference”, The map Collector 48, pp. 38-39.

SCOTT V. G., (1990), “The Jenkinson map”, The Map Collector 52, p. 29.

SZYKUŁA A K. (1989), "The Newly Jenkinson's Map of Russia of $1562 \mathrm{v}$, in $13^{\text {th }}$ International Conference on the History of Cartography, Amsterdam and the Hague, June 26 to July 1, 1989. Abstracts. Amsterdam 1989, pp. 109-111

SZYKUŁA K. (1990), “Odnalezienie mapy Rosji Jenkinsona z 1562 roku”, Polski Przeglad Kartograficzny, V. 22, nr 3, pp. 81-82. 
SZYKUŁA K. (1995a), “Jenkinson’s Map of Russia of 1562. Further investigations”, in $16^{\text {th }}$ International Conference on the History of Cartography, Vienna (Austria), 11-16 September 1995, Abstracts, p. 105.

SZYKUŁA K. (1995b), “Odnaleziona mapa Rosji Jenkinsona z 1562 roku. Pierwsza próba analizy mapy”, Acta Universitatis Wratislaviensis nr 1678, V. 2, Bibliothecalia Wratislaviensia, Wrocław, pp. 7-31.

SZYKUŁA K. (2000), “Mapa Rosji Jenkinsona (1562) - kolejne podsumowanie wyników badan”, Czasopismo Geograficzne, V. 71 (1), Wrocław, pp. 67-97 (this is the most important and fullest paper!).

SZYKUŁA K. (2005) ; “The Jenkinson Map of Russia (1562). A Research Summary”, Polish Library Today. Foreign Collections in Polish Libraries, Biblioteka Narodowa, Warszawa, V.6, pp. 57-69.

SZYKUŁA K. (2007), “Anthony Jenkinson’s unique wall map of Russia (1562) and its influence on European Cartography”, in Formatting Europe Mapping a Continent, Brussels, pp. 13-16.

\section{ABSTRACTS}

This paper deals with the only extant copy of the newly found map of Russia of 1562 purchased for the Wroclaw University Library cartographic collection and covering the eastern end of Europe. The map under consideration is the result of first travels of Englishmen searching for the route to China in the $16^{\text {th }}$ century. The original Jenkinson map rediscovered in 1987 was exhibited for the first time in a poster session of the 13th International Conference on the History of Cartography in Amsterdam in 1989. The map in question portrays the area from the Gulf of Finland to the region of Tashkent and Bukhara. Rediscovery of Jenkinson's original makes it possible to verify the fidelity of the Ortelius rendition only, not De Jode's which is also considered. It allows us to exclude speculations entertained by scholars to whom the only renditions were known before this event.

Several papers already published by the present and other authors have been written so far considering the subject from different points of view. In the later part of the paper, the present author proposes to analyze the influence of the rediscovered map on later cartography, i.e. whether Jenkinson's map influenced the image portrayed by the post-Jenkinson cartographers of the $16^{\text {th }}, 17^{\text {th }}$ and $18^{\text {th }}$ centuries.

Cet article traite du seul exemplaire encore existant de la carte de Russie de 1562 découverte récemment et venue enrichir la collection cartographique de la Bibliothèque de l'Université de Wroclaw. Couvrant la partie la plus orientale de l'Europe, cette carte résulte des premiers périples de voyageurs anglais à la recherche de la route de la Chine au XVI ${ }^{\mathrm{e}}$ siècle. La carte originale de Jenkinson, redécouverte en 1987 , fut exposée pour la première fois à l'occasion de la $13^{\mathrm{e}}$ Conférence Internationale consacrée à l'histoire de la cartographie à Amsterdam en 1989. Sur cette carte est représentée la zone s'étendant du Golfe de Finlande à la région de Tashkent et Bukhara.

La redécouverte de cet exemplaire original de Jenkinson permet de vérifier l'exactitude de la représentation d'Ortelius mais pas de celle de Jode, également prise en compte. Elle permet d'exclure les spéculations des spécialistes qui en connaissaient les seules représentations avant cet événement.

Plusieurs articles déjà publiés par nous-mêmes ou par d'autres ont traité ce sujet à partir de différents points de vue. Dans la deuxième partie de l'article, nous nous proposons d'analyser l'influence de la carte redécouverte sur la cartographie : en d'autres termes, la carte de Jenkinson 
a-t-elle influencé l'image dépeinte par les cartographes post-jenkinsonniens des $\mathrm{XVI}^{\mathrm{e}}, \mathrm{XVII}^{\mathrm{e}}$ et XVIII ${ }^{\mathrm{e}}$ siècles?

INDEX

Mots-clés: géographie, Russie au XVIe siècle, découverte, recherche de la route de la Chine, carte de Jenkinson

Keywords: geography, Russia 16th century, discovery, travels to search the way to China, Jenkinson's map

AUTHOR

KRYSTYNA SZYKUŁA

University of Wrocław, Poland, szykula@neostrada.pl 